\title{
Sustainable water use efficiency for rice cultivation in Rajshahi of Bangladesh
}

\author{
Sheikh Helena Bulbul, Md. Redwanur Rahman \\ Institute of Environmental Science, University of Rajshahi, Rajshahi-6205, Bangladesh \\ Email address: \\ hbsplendid07@gmail.com (S. H. Bulbul),redwan_rahman@lycos.com (M. R. Rahman)
}

To cite this article:

Sheikh Helena Bulbul, Md. Redwanur Rahman. Sustainable Water Use Efficiency for Rice Cultivation in Rajshahi of Bangladesh. American Journal of Agriculture and Forestry. Vol. 2, No. 4, 2014, pp. 146-153. doi: 10.11648/j.ajaf.20140204.17

\begin{abstract}
A field experiment was conducted at the Bangladesh Rice Research Institute, Shampur, Rajshahi to find out possible effects of alternate wetting and drying irrigation (AWDI) on the yield, water use and water use efficiency (WUE) of rice. The experimental plots were laid out with 2 factors RCBD combining two modern varieties of rice viz. BRRI dhan28 and BRRI hybrid2, which received four irrigation treatments randomly and was replicated thrice. The treatments ranged from continuous submergence $\left(T_{1}\right)$ of the field to a number of delayed irrigations $\left(T_{2}, T_{3}\right.$ and $\left.T_{4}\right)$ denoting application of 3, 5 and 7 days of disappearance of standing water respectively. The study revealed that treatment $\mathrm{T}_{1}$ attributed by the highest total water use $(49.04 \mathrm{~cm})$ and the lowest WUE $(60.62 \mathrm{~kg} / \mathrm{ha} / \mathrm{cm})$ produced the lowest grain yield (4.59 t/ha). Treatment $T_{2}$, on the contrary, gave the highest yield $(5.57 \mathrm{t} / \mathrm{ha})$ and consequently the higher WUE (85.55 $\mathrm{kg} / \mathrm{ha} / \mathrm{cm}$ ) than $T_{1}$ and indicating quite a large water saving (Application of 3 days of disappearance of Standing Water) compared to treatment $T_{1}$. The yields in treatments $T_{3}(5.33 \mathrm{t} / \mathrm{ha})$ and $\mathrm{T}_{4}(5.15 \mathrm{t} / \mathrm{ha})$ were significantly lower at $1 \%$ level of significance compared to that of treatment $T_{1}$. Significant effect was found either for the treatment or for the varieties on the number of effective and total tillers hill ${ }^{-1} 1000$ grain weight, plant height, number of effective tillers hill-1, grain yield, straw yield, biological yield and harvest index.
\end{abstract}

Keywords: Alternate Wetting and Drying (AWD), Sustainable Water Use Efficiency, Rice Cultivation

\section{Introduction}

The northwest region of Bangladesh broadly covers the whole Rajshahi Division, consisting of 16 districts of the country. The region is classified as medium- to high-land and is normally flood-free. Within the north-western region, the greater districts of Rajshahi, Dinajpur, Pabna, Rangpur and Bogra fall in the Barind Tract. Compared to the rest of Bangladesh, its Northwest has relatively unfavorable climatic conditions for agriculture. Ninety percent of its rainfall of 1200 to $1400 \mathrm{~mm}$ occurs within the three month period, June to August. Because of the nature of the soils and the monsoonal downpour, much of this rainfall is lost as surface runoff and causes considerable soil erosion. During the dry period of seven to eight months, evapotranspiration exceeds precipitation. In addition, the length of the monsoon varies considerably and extremes of temperature are experienced with many summer days above $400^{\circ} \mathrm{C}$ and several winter days below $50^{\circ} \mathrm{C}$. [1] reported the topsoil is very thin (often sandy) and beneath there is a hard clay pan. Furthermore points out that the organic content of the soil is low (organic matter accounts for only 0.5 to $0.7 \%$ of the soil content) and that the soil is deficient in plant nutrients such as nitrogen, in zinc and sulphur and trace elements. Considering all these aspects, northwest Bangladesh is a marginal area for agriculture, particularly crop growing. The major portion of the cropland of the Barind Tract is used for rice production and most of this rice land is now shown with High Yielding Varieties (HYV) of rice.

But paddy is a high user of water and encouragement of its production in a water-scarce region is risky, especially since it may quickly degrade the poor soil of this region. Government policy has been to encourage intensification of cultivation in this region including the increased of HYV rice. To this end, it established the Barind Integrated Area Development Project (BIADP) within the Ministry of Agriculture. Against advice from foreign experts, deep tube wells are being installed in this region under this project. One problem is that the use of water from underground sources is liable to exceed the rate of recharge of the 
aquifers. The actual and planned water supplies from these sources are in all probability unsustainable in the long-term. Already water tables have fallen in some areas. For example, mango trees are reported to have died in some areas around Rajshahi due to falling water tables.

Irrigation from underground sources has enabled the area doubled cropped and triple cropped to be substantially increased. This raises the rate of depletion of soil nutrients and accelerates soil erosion. Hence, reports of HYV (rice) yields of $2.6 \mathrm{t} / \mathrm{ha}$ decreasing to around $2.0 \mathrm{t} / \mathrm{ha}$ or lower (even only $1.2 \mathrm{t} / \mathrm{ha}$ ) in many areas, are common in recent years [2]. Consequently several reports and papers highlight the lack of sustainability of current agricultural practices in this region and there is significant land degradation with evidence of desertification in some areas [3]. In addition, it seems probable that current and planned supplies of underground water for irrigation particularly in rice cultivation are unsustainable.

Farmers of this region used continuously standing water for rice cultivation. It is true that rice cultivation requires much water than any other crops. It may also be that high yield in this result in a strong time preference for present water use pattern and a belief that the long-term will somewhat take care itself. This raises several questions in political economy. In particular why should the government support agricultural developments which, on the face of it, result in unsustainable increases in income?

This study is significant as it reveals an effective, yet unexplored (in terms of variety) mode of irrigation system (alternate wetting and drying), that can save water and cost and contribute to sustainability. In order to irrigate paddy field, electricity or fuel is needed to bring water to the surface. Water pumping and delivery treatment facilities consume a significant amount of energy. Farmers are currently paying an equivalent of $25 \%$ to $30 \%$ of their rice harvest for irrigation and these costs are tending to increase [4]. This presents another factor for the economic relevance of water-saving at the farm level.

Experts state that on a national level, the implementation of AWD could save costs for irrigation of up to 56.4 million Euros in electricity or 78.8 million Euros in fuel (30 liter diesel/ha) [5]. In some regions of the world over $15 \%$ of total electricity consumption is devoted to water management. However, the demand for energy grossly exceeds the available supply by far [6]. Diesel is not always available in some rural areas and is expensive for poor rice farmers, while farmers connected to a public power grid are subject to frequent power cuts [7]. In order to address farmers' needs to save water, energy and fuel in irrigated rice alternate Wetting and Drying technology, which takes an average of 1,432 litters of evapotranspirated water to produce $1 \mathrm{~kg}$ of rough rice [8]. The total production costs for the Boro season for conventionally irrigated rice ranged in Bangladesh in 2009 from 475 Euros in Rajshahi [10] to 1010 Euros in Camilla [9]. Of these total costs between $12 \%$ (Chittagong) and 27\% (Rajshahi) were irrigation costs, ranging in 2009 between 54 Euros/ha [10] and 226
Euros/ha [9] through implementing AWD-based irrigation between 15 Euros/ha and 112euros/ha [9] could be theoretically saved, i.e. if water and energy savings were transferred to the farmer. It access to contribute to environmental sustainability.

As irrigated rice systems serve as a large sink for atmospheric carbon dioxide and are a significant source of methane [11], it is assumed that reducing the standing water in rice fields will have positive ecological implications.

Water is integrally linked to the health of the environment. Water is vital to the survival of ecosystems and the plants and animals that live in them, and in turn ecosystems help to regulate the quantity and quality of water. Alternate wetting and drying water saving technology can helpful for habitat conservation. Minimizing irrigation water use helps to conserve wetland habitats for indigenous flora and fauna and migrating waterfowl.

Therefore, introducing AWD could have major impacts at the farm level and be important throughout the country by reducing irrigation costs and reducing the excessive use of ground water, leading to a more sustainable use of natural resources.

So, the judicial use of water resources in intensive irrigated area is a crucial need for maintaining both sustainable crop production and accessible water level.

\subsection{The Objectives of the Research Were}

- To identify the sustainable water use efficiency for rice cultivation by practicing alternate wetting and drying (AWD).

- To determine the water use efficiency and water productivity of AWD for Boro rice.

- To analyze impact of wetting and drying on yield and yield contributing characters.

\section{Materials and Methods}

The Bangladesh Rice Research Institute (BRRI) Farm of Shampur, Rajshahi was selected as the experimental site. Topography of the land being plain was suitable for check basin irrigation. Individual plots were located inside a close growing rice field so that actual growing condition (reception of the direct and diffused fluxes) prevails in the site.

The experimental plots $(4 \times 2.5 \mathrm{~m})$ were laid out with 2 factors RCBD combining two modern varieties of rice (BRRIdhan 28 and BRRI hybrid2) and four irrigation treatments that were replicated thrice. This resulted in a total of 24 plots in the field with 8 plots in a row. Each of the plots was separated by $1 \mathrm{~m}$ of transition zone while each of the replications was demarcated by a buffer zone of $1.5 \mathrm{~m}$ in between. To prevent seepage, polythene sheets were pushed into the edges of the levees along the inner perimeter of all plots. PVC pipes of $4 \mathrm{~cm}$ in diameter and $40 \mathrm{~cm}$ in length were installed in the field keeping $7 \mathrm{~cm}$ above the soil and the remaining $33 \mathrm{~cm}$ which was 
perforated underneath to measure the depletion of soil water in the field. Irrigation water was applied when depleting water table inside the pipe reached a certain level.

The first treatment (T1) was continuous submergence (1 to $5 \mathrm{~cm}$ standing water; maintained throughout the growing season) and the remaining three $\left(\mathrm{T}_{2}, \mathrm{~T}_{3}\right.$ and $\left.\mathrm{T}_{4}\right)$ stood for an application of 3, 5 and 7 days of disappearance of standing water respectively. Continuous standing water $(5 \mathrm{~cm})$ was maintained in all plots up to 28 days after transplantation (DAT) to avoid pre-apprehended weed infestation that could be awesome during crop establishment stage. A bowl of 1.5 liters was used to irrigate the plots from the buffer zones by throwing water in. The seedlings were transplanted maintaining hill to hill distance of $15 \mathrm{~cm}$ and row to row distance of $25 \mathrm{~cm}$. The first and the last hills were kept at $7.5 \mathrm{~cm}$ away from their nearest levees resulting in 25 hills along the length and 10 hills along the width. Since the grains of BRRI hybrid 2 got ripened earlier than the BRRIdhan 28, the former was harvested (23 April 2011) two weeks earlier than the harvesting date (May 12, 2011) of the latter. Matured plants inside $1 \mathrm{~m}$ square of land were harvested for subsequent analysis. Moisture content of the grains, however, was adjusted to $14 \%$ equivalent moisture content after measuring through digital grain moisture meter for subsequent analysis. Quantitative information related to yield and all the yield contributing characters viz. plant height, effective tillers, length of the panicle, no. of spikelets per panicle, no. of filled and unfilled grains per panicle, 1000 grain weight, grain yield, straw yield, harvest index and water use efficiency of the two varieties (BRRIdhan 28 and BRRI hybrid2) were analyzed to obtain the effect for AWDI on rice production.

\section{Results and Discussion}

Significant consequences of AWDI on the production of Boro rice were observed as given in Table 1. The analysis showed that varietal effect on plant height was statistically significant at $1 \%$ probability level. The tallest plant $(104.50 \mathrm{~cm})$ was found in BRRI hybrid2 $\left(\mathrm{V}_{2}\right)$. The shortest plant $(101.64 \mathrm{~cm})$ was found in BRRI dhan28 $\left(\mathrm{V}_{1}\right)$. Variation in plant height might be due to the differences in the genetic make-up of the varieties. The result is in consistent with findings of [12] who also reported a variable plant height existed among the varieties. The highest number of total tillers hill-1(11.75) was found in BRRI hybrid2 and the lowest number of total tiller was found (10.88) in BRRI dhan28. The variation in number of total tillers hill $^{-1}$ might be due to varietal characteristics. Number of effective tillers hill ${ }^{-1}$ was statistically significant at $1 \%$ level of probability. The highest number of effective tillers (9.53) was found in BRRI hybrid2 and the lowest number of effective tiller hill $^{-1}(8.79)$ was found in BRRI dhan28. The highest number of non-effective tillers (2.21) was found in BRRI dhan 28 and the lowest number of noneffective tiller hill $^{-1}(2.09)$ was found in BRRI hybrid2. The highest length of panicle $(23.65 \mathrm{~cm})$ was found in BRRI hybrid2. The lowest length of panicle was $(23.35 \mathrm{~cm})$ in BRRI dhan28. Varietal differences regarding the panicle length might be due to their differences in genetic make-up. Number of filled grains panicle ${ }^{-1}$ was statistically significant at $1 \%$ level of probability. The results showed that the highest grain yield (149.92) was achieved from BRRI hybrid2. The lowest grain yield (118.45) was achieved from BRRI dhan28. These differences occurred due to variations of genetic make-up among the varieties. Number of unfilled grains panicle ${ }^{-1}$ was statistically significant at $1 \%$ level of probability. The highest number of unfilled grains panicle ${ }^{-1}$ (30.80) was found in BRRI dhan28. The lowest number of unfilled grains (23.53) panicle $^{-1}$ was found from BRRI hybrid2. The result showed that the highest weight of 1000 - grain $(25.62 \mathrm{~g})$ was obtained from BRRI hybrid2. The lowest weight of 1000grain (23.93g) was obtained from BRRI dhan28. Grain yield was statistically significant at $1 \%$ level of probability. The highest grain yield (5.52t/ha) was achieved from BRRI hybrid2. The lowest grain yield $(4.81 \mathrm{t} / \mathrm{ha})$ was achieved from BRRI dhan28. These differences occurred due to variations of genetic make-up among the varieties. The result reveals that the highest straw yield $\left(6.58\right.$ tha $\left.^{-1}\right)$ was found from BRRI hybrid2. The lowest straw yield (5.71tha $\left.{ }^{1}\right)$ was found from BRRI dhan28.The highest yield occurred due to higher plant height, higher total tiller hill ${ }^{-1}$ and lower number non-effective tiller hill $^{-1}$. These results are consistent with those obtained by [13] who reported differences in straw yield among varieties. The highest biological yield $\left(12.10\right.$ tha $\left.^{-1}\right)$ was obtained from BRRI hybrid2 and the lowest one $\left(10.52\right.$ tha $\left.^{-1}\right)$ was obtained from BRRI dhan28. Maximum harvest index (45.63\%) was obtained from BRRI dhan28 and the minimum harvest index (45.57\%) was obtained from BRRI hybrid2.

Table 1. Varietal (BRRI dhan28 and BRRI hybrid2) Effect on the Yield and Yield Contributing Characters.

\begin{tabular}{|c|c|c|c|c|}
\hline Variety & $\mathrm{V}_{1}$ & $\mathbf{V}_{2}$ & LSD & Level of sig \\
\hline Plant height (cm) & 101.64 & 104.50 & 0.28 & $* *$ \\
\hline Total tiller hill ${ }^{-1}$ & 10.88 & 11.75 & 0.08 & $* *$ \\
\hline Effective tiller hill ${ }^{-1}$ & 8.79 & 9.53 & 0.09 & NS \\
\hline Non-effective tiller hill ${ }^{-1}$ & 2.09 & 2.21 & 0.10 & NS \\
\hline Panicle length $(\mathrm{cm})$ & 23.35 & 23.65 & 0.18 & $* *$ \\
\hline Filled grain panicle ${ }^{-1}$ & 126.33 & 149.92 & 0.77 & $* *$ \\
\hline Unfilled grain panicle $^{-1}$ & 30.80 & 23.53 & 0.59 & $* *$ \\
\hline 1000-GW & 23.93 & 25.62 & 0.18 & $* *$ \\
\hline Grain yield $\left(\mathrm{t} \mathrm{ha}^{-1}\right)$ & 4.81 & 5.52 & 0.05 & $* *$ \\
\hline Straw yield $\left(\mathrm{t} \mathrm{ha}{ }^{-1}\right)$ & 5.71 & 6.58 & 0.05 & $* *$ \\
\hline Biological yield & 10.52 & 12.10 & 0.07 & $* *$ \\
\hline Harvest Index & 45.63 & 45.57 & 0.33 & NS \\
\hline
\end{tabular}

In a column figures with same letter or without letter do not differ significantly whereas figures with dissimilar letter differ significantly (as per DMRT), $\mathrm{V}_{1}=$ BRRI dhan $28, \mathrm{~V}_{2}=$ BRRI hybrid $2, \mathrm{NS}=\mathrm{Not}$ Significant, $*=$ Significant at $5 \%$ level of probability, $* *=$ Significant at $1 \%$ level of probability. 
The experiment aimed in exploring the possible effects of different irrigation treatments on the production and production related parameters. Different yield contributing characters viz., plant height $(\mathrm{cm})$, number of effective tillers per hill, panicle length $(\mathrm{cm})$, total number of filled grains per panicle, number of unfilled grains per panicle; 1000 seed weight $(\mathrm{gm})$, grain yield $(\mathrm{t} / \mathrm{ha})$ and straw yield ( $t /$ ha)for each of the varieties were analyzed.

Results obtained from the statistical analysis of the effect of different degrees of delayed irrigation treatments on plant height are shown in table 2 . The analysis showed that the irrigation treatments had significant effect on plant height at $1 \%$ level of probability. The highest plant height $\left(104.38 \mathrm{~cm}\right.$ ) was obtained in treatment $\mathrm{T}_{2}$ (Application of 3 days of disappearance of standing water) and the lowest $(101.55 \mathrm{~cm})$ in Treatment $T_{1}$ (continuous flooding) as shown in figure 1.

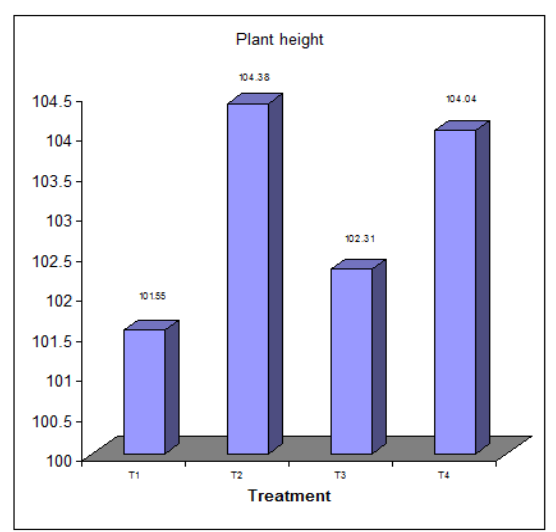

Figure 1. Variation in Plant Height for Different Degrees of Irrigation Treatments.

Information obtained after analysis of the experimental findings showed that effect on the number of effective tillers quite significant at $1 \%$ level of probability while different degrees of delayed irrigations applied as treatments in the experimental plots. The highest number of effective tillers per hill (11.65) was found in treatment $\mathrm{T}_{2}$ followed by treatment $T_{3}(8.69)$ and treatment $T_{1}(8.45)$. The lowest number of effective tiller per hill (7.85) was found in treatment $\mathrm{T}_{4}$. A little delayed irrigation treatments using alternate wetting and drying irrigating method in rice field showed significant effects on the number of filled grains per panicle compared to one with continuous standing. It was found that the highest number of filled grains (150.55) per panicle was obtained in treatment $T_{2}(3$ days of disappearance of standing water) followed by treatments $T_{3}(141.65)$ and $T_{4}(139.47)$. The lowest number of filled grains per panicle (120.84) was found for treatment $T_{1}$. Thus the result showed that applying irrigation water in rice field when 3 days of disappearance of standing water does not really reduce the total number of filled grains compared to that nursed with $5 \mathrm{~cm}$ standing water (Figure 1). However, treatment $\mathrm{T}_{1}$ (continuous standing water) decreased the number of filled grains. Grain yield, the most important character of an agronomic analysis, was found to be significantly influenced by varieties, different degrees of AWDI irrigation treatments. Analysis of the data obtained from the experimental plots resulted in a clear depiction of the scenario. The highest grain yield $(5.57 \mathrm{t} / \mathrm{ha})$ was obtained from treatment $\mathrm{T}_{2}$ (irrigation when water is 3 days of disappearance of standing water) and the lowest yield grain (4.59t/ha) was obtained from treatment $\mathrm{T}_{1}$ (continuous standing water). The results shows that the grain yield did not decreased when plants suffered little water stress. The second highest yield grain $(5.33 \mathrm{t} / \mathrm{ha})$ was found in the treatment $\mathrm{T}_{3}(5$ days of disappearance of standing water). [14] and [15] have shown that rice grain yield increased with reduced water use. Straw yield from the experiment was found to be significantly affected by the variety, irrigation treatments. The maximum straw yield $(6.45 \mathrm{t} / \mathrm{ha})$ was found from the treatment $\mathrm{T}_{2}$. The minimum straw yield $(6.00 \mathrm{t} / \mathrm{ha})$ was found from treatment $T_{1}$.

Results obtained from the statistical analysis of the effect of variety and different degrees of delayed irrigation treatments on plant height are shown in table 3 . The analysis showed that effect of the interaction between the varieties and the treatments was also found to be statistically significant at $1 \%$ level of probability.

Table 2. Effect of Different Irrigation Treatments on the Yield and Yield Contributing Characters.

\begin{tabular}{|c|c|c|c|c|c|c|}
\hline Treatment & $\mathbf{T}_{1}$ & $\mathbf{T}_{2}$ & $\mathbf{T}_{3}$ & $\mathbf{T}_{4}$ & LSD & Level of sig \\
\hline Plant height $(\mathrm{cm})$ & $101.55 b$ & $104.38 \mathrm{a}$ & $102.31 b$ & $104.04 \mathrm{a}$ & 0.57 & $* *$ \\
\hline Total tiller hill-1 & $10.92 \mathrm{c}$ & $12.94 \mathrm{a}$ & $11.64 b$ & $9.76 \mathrm{~d}$ & 0.16 & $* *$ \\
\hline Effective tiller hill $^{-1}$ & $8.45 b$ & $11.65 \mathrm{a}$ & $8.69 b$ & $7.85 \mathrm{c}$ & 0.19 & $* *$ \\
\hline Non-effective tiller hill $^{-1}$ & $2.47 \mathrm{a}$ & $1.29 \mathrm{c}$ & $2.95 \mathrm{a}$ & $1.91 \mathrm{~b}$ & 0.20 & $* *$ \\
\hline Panicle length $(\mathrm{cm})$ & $23.07 \mathrm{~b}$ & $24.48 \mathrm{a}$ & $22.91 b$ & $23.53 b$ & 0.35 & $* *$ \\
\hline Filled grain panicle $^{-1}$ & $120.84 c$ & $150.55 \mathrm{a}$ & $141.65 b$ & $139.47 b$ & 1.53 & $* *$ \\
\hline Unfilled grain panicle $^{-1}$ & $31.72 \mathrm{a}$ & $23.58 b$ & $24.03 b$ & $29.34 \mathrm{a}$ & 1.17 & $* *$ \\
\hline 1000-GW & $23.97 b$ & $25.27 \mathrm{a}$ & $25.27 \mathrm{a}$ & $24.60 \mathrm{ab}$ & 0.36 & $* *$ \\
\hline Grain yield $\left(\mathrm{t} \mathrm{ha}^{-1}\right)$ & $4.59 b$ & $5.57 \mathrm{a}$ & $5.33 \mathrm{ab}$ & $5.15 \mathrm{ab}$ & 0.09 & $* *$ \\
\hline Straw yield $\left(\mathrm{t} \mathrm{ha}^{-1}\right)$ & $6.00 \mathrm{~b}$ & $6.45 \mathrm{a}$ & $6.04 b$ & $6.10 \mathrm{~b}$ & 0.09 & $* *$ \\
\hline Biological yield & $10.59 \mathrm{c}$ & $12.02 \mathrm{a}$ & $11.37 \mathrm{~b}$ & $11.25 b$ & 0.13 & $* *$ \\
\hline Harvest Index & $43.46 \mathrm{~b}$ & $46.26 \mathrm{a}$ & $46.90 \mathrm{a}$ & $45.77 \mathrm{a}$ & 0.65 & $* *$ \\
\hline
\end{tabular}

In a column figures with same letter or without letter do not differ significantly whereas figures with dissimilar letter differ significantly (as per DMRT), $\mathrm{T}_{1}=$ Continuous Standing water, $\mathrm{T}_{2}=3$ days disappearance of standing water, $\mathrm{T}_{3}=5$ days disappearance of standing water, $\mathrm{T}_{4}=7$ days disappearance of standing water, NS $=$ Not Significant, $*=$ Significant at $5 \%$ level of probability, $* *=$ Significant at $1 \%$ level of probability. 
The tallest plant height $(106.48 \mathrm{~cm})$ was found for the interaction $\mathrm{V}_{2} \times \mathrm{T}_{2}$. Information obtained after analysis of the experimental findings showed that the interaction effect of the varieties and treatments also came significant at $1 \%$ level of probability. The highest number of filled grains (158.67) was, however, marked for the interaction $\left(\mathrm{V}_{2} \times \mathrm{T}_{2}\right)$ and the lowest number of filled grains (105.48) was obtained from $\mathrm{V}_{1} \mathrm{~T}_{1}$. Thousand grain weight (1000 grain weight), as it is called the test weight of the desired output, is referred to be considered as one of the most significant agronomic parameters ever trusted that contributes in having a reconnaissance over the possible production of a lot (gain yield). The values of 1000 grain weight were found to be significant in this analysis for the effects of treatments at the $1 \%$ level of probability. The highest 1000 grain weight (26.82) was obtained for the interactions $\left(\mathrm{V}_{2} \times \mathrm{T}_{3}\right)$ and the lowest 1000 grain weight (23.63) was obtained for the $\mathrm{V}_{2} \mathrm{~T}_{4}$. The study raveled that the varieties $V_{1}$ and $V_{2}$ and interaction effect between variety $\times$ treatments produced statistically insignificant variation in 1000 grain weight among themselves. Thus, it was clear from the interaction effect that AWDI method of irrigation treatments did not reduced the 1000 grain weight as irrigation delayed. Grain yield, the most important character of an agronomic analysis, was found to be significantly influenced by varieties, different degrees of AWDI irrigation treatments and their interactions. Analysis of the data obtained from the experimental plots resulted in a clear depiction of the scenario. It showed that the varietal effect on the grain yield was significant at the $1 \%$ level of probability (Table 3 ).

The interaction between the varieties and treatment also produced significant results for grain yield at the $1 \%$ level of probability. The highest grain yield of BRRI hybrid2 $(6.16 \mathrm{t} / \mathrm{ha})$ was obtained for the interaction $\left(\mathrm{V}_{2} \times \mathrm{T}_{2}\right)$ and the lowest grain yield $(4.06 \mathrm{t} / \mathrm{ha})$ was obtained from the interaction $\left(\mathrm{V}_{1} \times \mathrm{T}_{1}\right)$. Straw yield from the experiment was found to be significantly affected by the variety, irrigation treatments and their combination at $1 \%$ level of probability. The highest straw yield (6.94t/ha) was obtained for the interaction $\left(\mathrm{V}_{2} \times \mathrm{T}_{2}\right)$ and lowest straw yield (5.11t/ha) was obtained for the interaction $\left(\mathrm{V}_{1} \times \mathrm{T}_{1}\right)$ (Table 3$)$.

\subsection{Irrigation Treatments (AWDI)}

The two varieties stated above were subjected to different levels of irrigation developed by delaying the scheduled irrigation in the field. Starting from the very end of the first stage of crop development, four irrigation treatments were started with regular intervals. The time of water application, however, was indicated by the depletion of water level in different perforated pipes measured from the ground surface. Both of the experimental rice varieties, irrespective of their position in the field, receive different levels of irrigation treatments according to the demand of the respective fields in each replication.

Irrigation treatments were applied at different stages of the growing period depending on the depletion of the water level in the perforated pipe. The very first treatment stated at the end of the fourth week after transplantation. During this time $5 \mathrm{~cm}$ standing water was kept to avoid weed infestation in the plots.

Table 4 shows that the highest number of irrigation (15nos.) was given to the plots with treatment $T_{1}$ (continuous flooding) for BRRI dhan28. The other three treatments viz., $\mathrm{T}_{2}, \mathrm{~T}_{3}$ and $\mathrm{T}_{4}$ received a total of 14,13 and 13 number of irrigation for BRRI dhan28 while 14, 13, 13 and 12 number of irrigation for BRRI hybrid2, respectively.

Table 3. Mean effect of the Interaction Between Varieties and Irrigation Treatments on the Yield and Yield Contributing Characters of BRRI dhan28 (VI) and BRRI hybrid2 $\left(V_{2}\right)$

\begin{tabular}{|c|c|c|c|c|c|c|c|c|c|c|}
\hline & $\mathbf{V}_{1} \mathbf{T}_{1}$ & $V_{1} T_{2}$ & $\mathbf{V}_{1} \mathbf{T}_{3}$ & $V_{1} T_{4}$ & $\mathbf{V}_{2} \mathbf{T}_{1}$ & $V_{2} T_{2}$ & $\mathbf{V}_{2} \mathbf{T}_{3}$ & $\mathbf{V}_{2} \mathbf{T}_{4}$ & LSD & $\begin{array}{l}\text { Level of } \\
\text { sig }\end{array}$ \\
\hline Plant height $(\mathrm{cm})$ & $98.51 \mathrm{e}$ & $102.28 \mathrm{~cd}$ & $101.29 \mathrm{~d}$ & $104.48 \mathrm{ab}$ & $104.59 \mathrm{ab}$ & $106.48 \mathrm{a}$ & $103.34 \mathrm{bcd}$ & $103.60 \mathrm{bc}$ & 1.13 & $* *$ \\
\hline Total tiller hill ${ }^{-1}$ & 10.45 & 12.41 & 11.38 & 9.30 & 11.39 & 13.47 & 11.90 & 10.22 & 0.32 & NS \\
\hline Effective tiller hill ${ }^{-1}$ & 8.01 & 11.43 & 8.26 & 7.46 & 8.90 & 11.87 & 9.12 & 8.23 & 0.37 & NS \\
\hline Non-effective tiller hill-1 & 2.44 & 0.98 & 3.11 & 1.84 & 2.49 & 1.60 & 2.78 & 1.98 & 0.41 & NS \\
\hline Panicle length $(\mathrm{cm})$ & 22.83 & 24.16 & 23.02 & 23.38 & 23.31 & 24.80 & 22.80 & 23.67 & 0.70 & NS \\
\hline Filled grain panicle ${ }^{-1}$ & $105.48 \mathrm{f}$ & $142.42 \mathrm{c}$ & $129.17 \mathrm{e}$ & $128.26 \mathrm{e}$ & $136.20 \mathrm{~d}$ & $158.67 \mathrm{a}$ & $154.13 \mathrm{ab}$ & $150.67 b$ & 3.07 & $* *$ \\
\hline Unfilled grain panicle $^{-1}$ & $38.31 \mathrm{a}$ & $25.90 \mathrm{c}$ & $24.95 \mathrm{~cd}$ & $34.04 b$ & $25.13 \mathrm{~cd}$ & $21.27 \mathrm{~d}$ & $23.10 \mathrm{~cd}$ & $24.63 \mathrm{~cd}$ & 2.35 & $* *$ \\
\hline 1000-GW & 23.91 & 24.46 & 23.71 & 23.63 & 24.03 & 26.07 & 26.82 & 25.57 & 0.72 & NS \\
\hline Grain yield $\left(\mathrm{t} \mathrm{ha}^{-1}\right)$ & $4.06 \mathrm{c}$ & $4.98 b c$ & $4.96 \mathrm{bc}$ & $5.21 \mathrm{abc}$ & $5.12 \mathrm{abc}$ & $6.16 \mathrm{a}$ & $5.70 \mathrm{ab}$ & $5.09 \mathrm{abc}$ & 0.19 & $* *$ \\
\hline Straw yield $\left(\mathrm{t} \mathrm{ha}^{-1}\right)$ & $5.14 \mathrm{e}$ & $5.96 \mathrm{c}$ & $5.63 \mathrm{~d}$ & $6.11 \mathrm{c}$ & $6.85 \mathrm{a}$ & $6.94 a$ & $6.45 b$ & $6.09 \mathrm{c}$ & 0.19 & $* *$ \\
\hline Biological yield & $9.20 \mathrm{e}$ & $10.94 \mathrm{~cd}$ & $10.59 \mathrm{~d}$ & $11.33 \mathrm{c}$ & $11.97 \mathrm{~b}$ & $13.09 \mathrm{a}$ & $12.15 b$ & $11.17 \mathrm{c}$ & 0.26 & $* *$ \\
\hline Harvest Index & 44.13 & 45.49 & 46.86 & 46.02 & 42.79 & 47.02 & 46.93 & 45.52 & 1.30 & NS \\
\hline
\end{tabular}

In a column figures with same letter or without letter do not differ significantly whereas figures with dissimilar letter differ significantly (as per DMRT), * $=$ Significant at $5 \%$ level of probability, $* *=$ Significant at $1 \%$ level of probability, NS $=$ Not significant. 
Table 4. Total number of irrigation required for different irrigation treatments.

\begin{tabular}{|c|c|c|c|c|c|}
\hline \multirow{2}{*}{ Treatment } & \multicolumn{2}{|c|}{ *No. of Irrigation } & \multirow{2}{*}{$\begin{array}{l}\text { Rainfall+ water for crop established }(\mathrm{cm}) \\
42.1\end{array}$} & \multicolumn{2}{|c|}{ Total water required(cm) } \\
\hline & BRRIdhan28 & BRRI hybrid2 & & BRRI dhan28 & BRRI hybrid2 \\
\hline $\mathrm{T}_{1}$ & 15 & 14 & 42.1 & 53.27 & 44.89 \\
\hline $\mathrm{T}_{2}$ & 14 & 13 & 42.1 & 52.67 & 43.79 \\
\hline $\mathrm{T}_{3}$ & 13 & 13 & 42.1 & 51.73 & 42.69 \\
\hline $\mathrm{T}_{4}$ & 13 & 12 & 42.1 & 51.42 & 42.69 \\
\hline
\end{tabular}

*One irrigation means application of $5 \mathrm{~cm}$ irrigation water

Water required for crop establishment and water received from the rainfall was estimated to be $42.1 \mathrm{~cm}$ during the growing period for each of the treatments. For BRRI hybrid2, maximum amount of water $(44.89 \mathrm{~cm})$ was required for $T_{1}$, while, second maximum $(43.79 \mathrm{~cm})$ for $T_{2}$ was followed by other two treatments, $\mathrm{T}_{3}(42.69 \mathrm{~cm})$ and $\mathrm{T}_{4}$ $(42.69 \mathrm{~cm})$. For BRRI dhan28 the treatments $\mathrm{T}_{1}, \mathrm{~T}_{2}, \mathrm{~T}_{3}$ and $\mathrm{T}_{4}$ required $53.27,52.67,51.73$ and $51.42 \mathrm{~cm}$ of water, respectively. The graphical representation of water usage by different treatments after transplantation is shown in figure 2 .

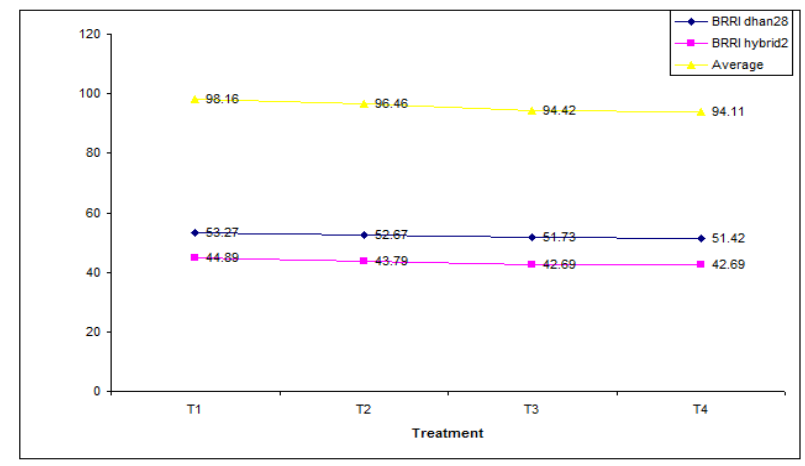

Figure 2. Water Usage of Different Treatments for the Production of BRRI dhan 28 and BRRI hybrid2.

Water use efficiencies for the individual effect of different treatments were derived along with the values of WUE for the 8 interactions between treatments and varieties (Table 5). The highest water use efficiency, WUE was found to be $81.67 \mathrm{~kg} / \mathrm{ha} / \mathrm{cm}\left(\mathrm{V}_{1} \times \mathrm{T}_{4}\right)$. All the highest water use efficiencies were found in the combinations having variety $\mathrm{V}_{1}$ (BRRI dhan28).

The lowest WUE $56.60 \mathrm{~kg} / \mathrm{ha} / \mathrm{cm}$ was obtained in the treatment $\mathrm{T}_{1}$ for $\mathrm{V}_{2}$ (Fig. 4.19). In case of BRRI dhan28 $\left(\mathrm{V}_{1}\right)$ the highest WU was found to be $81.67 \mathrm{~kg} / \mathrm{ha} / \mathrm{cm}$ in treatment $\mathrm{T}_{4}$ and the lowest WUE $64.64 \mathrm{~kg} / \mathrm{ha} / \mathrm{cm}$ in treatment $T_{1}$. The second highest WUE $(87.38 \mathrm{~kg} / \mathrm{ha} / \mathrm{cm})$ was found in the treatment $\mathrm{T}_{2}$ though it gave poor yield (4.98 t/ha). Treatment $\mathrm{T}_{4}$ gave high yield with high water use efficiency $(81.67 \mathrm{~kg} / \mathrm{ha} / \mathrm{cm})$ among the others (Figure 2$)$.

Water productivity was found to be the highest $(0.088$ $\mathrm{t} / \mathrm{ha} / \mathrm{cm}$ ) in treatment $\mathrm{T}_{4}$ (irrigation 5 days disappearance of standing) followed by treatment $\mathrm{T}_{4}$ and $\mathrm{T}_{2}(0.082 \mathrm{t} / \mathrm{ha} / \mathrm{cm})$ (irrigation 7 days and 3 days disappearance of standing water) and a minimum of $0.049 \mathrm{t} / \mathrm{ha} / \mathrm{cm}$ treatment $\mathrm{T}_{1}$ (continuous flooding). From these results, it can be seen that the water productivity decreased with the increase of irrigation water. Above result reveals on-farm strategies for reducing water input in irrigated rice [16].

This study shows that the alternate wetting and drying irrigation system has significant economic and environmental benefit for a farmer, the environment and the society. The system has better performance in generating profit even under worst case scenario. A little amount of input requirement and high yield capacity are the major reasons, enhancing the system's performance in a sustainable way. The practices of high-input agriculture are causing concerns about the sustainability of crop production.

Table 5. Water use Efficiency for Different Treatments and Interactions.

\begin{tabular}{|c|c|c|c|c|c|c|c|c|}
\hline Interactions & $V_{1} T_{1}$ & $V_{1} T_{2}$ & $\mathbf{V}_{1} \mathbf{T}_{3}$ & $V_{1} T_{4}$ & $\mathbf{V}_{2} \mathbf{T}_{1}$ & $\mathbf{V}_{2} \mathbf{T}_{2}$ & $V_{2} T_{3}$ & $\mathbf{V}_{2} \mathbf{T}_{4}$ \\
\hline Total water required $(\mathrm{cm})$ & 53.2 & 52.66 & 51.70 & 51.46 & 44.89 & 43.79 & 42.69 & 42.69 \\
\hline Water applied (cm) & 82.3 & 64.6 & 64.1 & 63.3 & 79.3 & 74.6 & 64.1 & 63.1 \\
\hline Grain Yield (ton/ha) & 4.06 & 4.98 & 4.96 & 5.21 & 5.12 & 6.16 & 5.70 & 5.09 \\
\hline Water use efficiency $(\mathrm{kg} / \mathrm{ha} / \mathrm{cm})$ & 64.64 & 81.42 & 80.65 & 81.67 & 56.60 & 58.69 & 66.59 & 66.59 \\
\hline Treatments & $\mathrm{T}_{1}$ & & $\mathrm{~T}_{2}$ & & $\mathrm{~T}_{3}$ & & $\mathrm{~T}_{4}$ & \\
\hline Average total water required $(\mathrm{cm})$ & 49.04 & & 48.22 & & 47.19 & & 47.07 & \\
\hline Average grain yield (ton/ha) & 4.59 & & 5.57 & & 5.33 & & 5.15 & \\
\hline Water use efficiency $\mathrm{kg} / \mathrm{ha} / \mathrm{cm}$ ) & 60.62 & & 70.05 & & 73.62 & & 74.13 & \\
\hline Water productivity $(\mathrm{t} / \mathrm{ha} / \mathrm{cm})$ & 0.049 & 0.077 & & 0.082 & 0.064 & 0.082 & 0.088 & 0.080 \\
\hline
\end{tabular}

There are many negative effects on the environment, including pollution by pesticides, emission of greenhouse gases, soil degradation, air pollution by dust, and loss of landraces and other biodiversity. People need to develop new techniques that will keep agriculture both profitable for the farmer and make it sustainable for the future.
There is a concern that the AWDI method of water management promotes greater weed populations, thus requiring more labor for weed management. [17] emphasized that even on coarse textured soils continuous submergence is only required for 3 week period after transplanting to ensure seedling establishment. The field 
may be drained for 1 to 5 days, depending on the weather, before the next irrigation. There will be no adverse effect on yield and 25 to $50 \%$ of water can be saved. [18] studied the effect of applying improved water management technology during the wet season in canal-irrigated rice fields in Bihar, India and found that irrigation to a depth of $7 \mathrm{~cm}, 3$ days after ponded water disappeared gave $34 \%$ more grain yield than the usual farmer's practice (more than $10 \mathrm{~cm}$ irrigation water continuously). A field experiment at the Bangladesh Agricultural University farm was conducted by [19] to compare the traditional water management practices in the rice field with the modern water saving techniques. The experiment was figured using split plot design and consisted of 5 irrigation treatments viz., Treatment $\mathrm{T}_{1}, \mathrm{~T}_{2}, \mathrm{~T}_{3}, \mathrm{~T}_{4}$ and $\mathrm{T}_{5}$ meaning continuous submergence, application of irrigation water 3 days, 5 days, 7 days and 10 days after the disappearance of standing water from the plots, respectively. They also reported an increase in plant height with the increase in water requirement though its effect on the production unit remained insignificant. $\mathrm{He}$ recommended that $5 \mathrm{~cm}$ irrigation water should be applied 3 days after the disappearance of standing water from the soil surface to obtain the maximum water use efficiency. An interval of 5 to 7 days between consecutive irrigations recommended [20]. It was also found that AFDI technique reduces continuous decline of water table.

However, a range of options are available for increasing the productivity and efficiency of water in surface irrigated rice ecologies. More radical options departing from traditional systems are also available and may be required.

The most appropriate strategies to adopt will vary over time and space and will have to be designed carefully with the involvement of the farmers, but will need to be resolutely forward-looking and perhaps revolutionary. Identifying the policies, management practices and technologies needed at farm, system and basin level will require a multi-disciplinary approach

\section{Conclusion}

The results of this research support the thesis that alternate wetting and drying treatment. The practice of keeping rice fields dry for some period of time during the growing season resulted in a significant reduction in water use. Maintaining the rice field dry during mid season not only reduced water use and significantly increased grain yield as compared to continuous flooding treatment if alternate wetting and drying practice is adopted.

Countrywide, particularly in the water major rice growing areas where groundwater is major source of irrigation and the farmers grow 2-3 rice crops per year, water use would significantly decrease. Using water more efficiently over several agro-ecological zones of the country would help alleviate water shortages allowing water to be used for other needs.

\section{References}

[1] Zuberi, M.I. "Natural Resource Management and Utilization in Bangladesh: on Irrigation and Drainage" Tokyo, Japan, 15-25 October 1989. I-C, pp. 480-Geological Survey WaterResources Investigation Report 84-4012, 1992, 47p.

[2] Zuberi, M.I. "A Description of North Western Bangladesh' (mimeo.) Centre for Environmental Research" 1993, University of Rajshahi, Rajshahi.

[3] Ministry of Forestry and IUCN. "Towards Sustainable Development: The National Conservation Strategy of Bangladesh" Ministry of Environment and Forestry, Dhaka, Bangladesh and IUCN, 1991, Glauds, Switzerland.

[4] M.A. Sattar, M. Maniruzzaman, and M.A. Kashem, (ed.) "National Workshop Proceedings on AWD Technology for Rice Production in Bangladesh" 2009, Bangladesh Rice Research Institute. Gazipur.

[5] M. Hamid; T.P. Tuong, B. Bouman and H. Elizabeth, "Dissemination, Spread and Adoption of Awd in Bangladesh" 2009, International Rice Research Institute, Dhaka, Bangladesh.

[6] Economist Intelligence Unit, "Bangladesh Country Profile" 2008. Economist. London.

[7] CPD (Centre for Policy Dialogue) "State of the Bangladesh Economy in FY 2009/10 From Stability to Accelerated Growth" 2010, Dhaka, Bangladesh.

[8] IRRI (International Rice Research Institute). "Site-Specific Nutrient Management" 2010, www.irri.org/ssnm.

[9] L. Kabir, "Benefit-cost Analysis of Demonstration on AWD Irrigation Method" 2009

[10] M. Hossain "Pumping up production: shallow tube wells and rice in Bangladesh" In: Spielman DJ, Pandaya-Lorch R(eds) Millions fed: proven successes in agricultural development. International Food Policy Research Institute, 2009, Washington, DC

[11] B.A. Bouman, M.L. Feng, T.P. Tuong, G. Lu, H. Wang and Y Feng, "Exploring options to grow rice under water-short conditions in northern China using a modeling approach" II: Quantifying yield, water balance components, and water productivity. Agricultural Water Management, 2007, vol. 88, pp. 23-33.

[12] A.M. Shamsuddin, M.A. Islam, and A. Hossain, "Comparative study on the yield and agronomic characters of nine cultivars of aus rice" Bangladesh J. Agril. Sci. 1988, vol. 15,1 , pp. 121-124.

[13] M.J.U. Chowdhury, A.U. Sarker, M.A.R. Sarker and M.A. Kashem, "Effect of variety and number of seedlings hill-1 on the yield and its components on late transplanted aman rice” Bangladesh J. Agril. Sci. 1993, vol. 20, 2. pp. 311-316.

[14] Q. Shi, X. Zeng, M.Li, X. Tan, and F. Xu. "Effect of different water management practices on rice growth" In: "Water-wise rice production" Bouman BAM, Hengisdijk H, Hardy B, Bindraban PS, Tuong TP, Ladha JK, (editors). 2002 . 
[15] I.P. Wardana, P.S. Bindraban, A. Gani, A.K. Makarim, and L. Isrel, "Biophysical and economic implications of integrated crop and resource management for rice in Indonesia". In: "Water-wise rice production" Bouman BAM, H Hengisdijk, Water-wise rice production. Proceedings of the international workshop on water wise rice production, 8-11 April 2002, Los Banos, Philippines. Los Banos (Philippines): International Rice1Research Institute. 2002, pp 3-13.

[16] D.F. Tabbal, B.A.M. Bouman, S.I. Bhuiyan, E.B. Sibayan and M. A. Sattar, "On-farm strategies for reducing water input in irrigated rice; case studies in the Philippine" Agric. Water Mange. 2002, vol. 56, pp. 93-112.

[17] K.L. Khera, B.S. Sandhu, and T.S. Aujla "Judicious irrigation saves water in rice cultivation" Indian Farming 1991, vol. 41, 2 pp. 27-28.
[18] K. Prasad, A.R.P. Bally, E.F. Schmid and Levy, J.C. Benoit, Barthou and P. Benalloul, "Ce-doped $\mathrm{TiO}_{2}$ insulators in thin film electroluminescent devices" Japanese J. Applied Phys., 1997 vol. 36, pp. 5696-5702.

[19] S.K. Jha, M.K. Hossain and M.S.U. Talukder, "Response of transplanted Boro rice under different irrigation practices" Bangladesh J. Agril. Unv. Bangladesh. 2007, vol 5, 2, pp. 393-398.

[20] Bangladesh Institute of Nuclear Agriculture (BINA) "Achievements of Non Commodity Technologies: Water saving in rice cultivation" Online publication ("http://hyperlink\%20\%22http//www.bina.gov.bd/\%22www. bina.gov.bd" ) of BINA, 2007, Mymensingh, Bangladesh. 